\title{
ラム醸造微生物学の進歩
}

ラムは糖蜜を原料としたスピリッツで，その耑要が製菓に限らず，飲用に着実に拡がりつつあるが，製造面で 酵母以外にバクテリヤの関与が大きい珍らしい酒である。長年月にわたってラムを研究して来られた筆者にこれ ら微生物の働らきとラム製造について解説していただいた。

薄井隆・根元茂

ラムは糖蜜または甘蔗汁を発酵し蒸留して作った酒で ある。一概にラムと言ってもその品質には非常な格差が あり，風味の濃厚なへヴィラム，淡色で軽い香味のライ トラム及びその中間の酒質のミディアムラムの 3 タイプ に大別されている。これらのラムの香気成分の含有量は

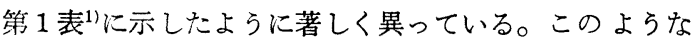
差異は蒸留方法の違いによっても生ずるが, 醪の組成や 調製法，酵母の種類などの発酵条件の差に由来するとこ ろが大きい。

これらのタイブの中で，以前はジャマイカラムに代表 されるへヴィタイプが主流を占めていたが，最近では全 般にライト化の傾向が強く見られライトラムが増えてき ている。またへヴィラムでもかつての製品ほどには濃厚 でなくなってきている。

ラムの製造に関与する微生物は勿論酵母が主体である が，バクテリヤも重要な役割を果している。これらに関 する研究は極めて少なく，また著者が入手し得た文献も その中の一部に限られているが，本稿ではその範囲内で ラムの微生物について解説を試みた。

\section{1. ラムの発酵}

徵生物について述べる前にまずラムの発酵に関して概 要を示す。

ラムの原料には主として廃糖蜜(Blackstrap molasses, 以下単に糖蜜と言う。）が用いられるが，精製糖蜜（Hi- ghtest molasses) や甘蔗汁が使用されることもある。糖 蜜にも第 2 表 $^{2}$ に示したように品質の差があり， ラムの 原料としては全糖と窒素分が多く，灰分やガム質の少な いものが良いとされている。

これを稀釈して醪を調製するが，この段階で必要に応 じて加熱，精製，遠心分離などの処理や， $\mathrm{pH}$ 調整，栄 養源の添加を行なら。醅の組成はラムのタイプや産地に よって異なるが一般的な成分を例示すれば， B × 15〜17 ， 全糖 $10 \sim 12 \%, \mathrm{pH} 5.5 \sim 5.8$, 滴定酸度 $1.5 \sim 2.0 \mathrm{ml}$, 窒素 $200 \sim 250 \mathrm{mg} \%$ ，リン $60 \sim 75 \mathrm{mg} \%\left(\mathrm{P}_{2} \mathrm{O}_{5}\right.$ とし て）である3”。Bx $22^{\circ}$ 以上では完全発酵が難しいが, Bx $24 \sim 26^{\circ}$ といら高濃度醪を段掛け法で発酵させたと いら報告があり3)，これによれば醪を 2 時間以内の間隔 で8回に分けて発酵タンクに投入したところ発酵は30〜 36時間で完了し，醪のアルコール分は 8〜10\% であっ た。

第 2 表 糖蜜の成分

\begin{tabular}{|c|c|c|c|}
\hline & 上 等 品 & 中 等 品 & 下 等 品 \\
\hline プリックス & 87.6 & 85.4 & 88.2 \\
\hline 全 糖 & 58.0 & 52.9 & 49.9 \\
\hline 蔍 & 36.4 & 31.3 & 34.6 \\
\hline 化 糖 & 19.6 & 20.0 & 13.5 \\
\hline Ex & 7.3 & 9.4 & 11.6 \\
\hline 窒 素 & 1.1 & 0.6 & 0.5 \\
\hline ガ & 2.0 & 2.6 & 3.8 \\
\hline 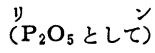 & 0.2 & 0.1 & 0.2 \\
\hline $\mathrm{pH}$ & 5.5 & 5.7 & 6.3 \\
\hline
\end{tabular}

第1表 各種 ラムの成分

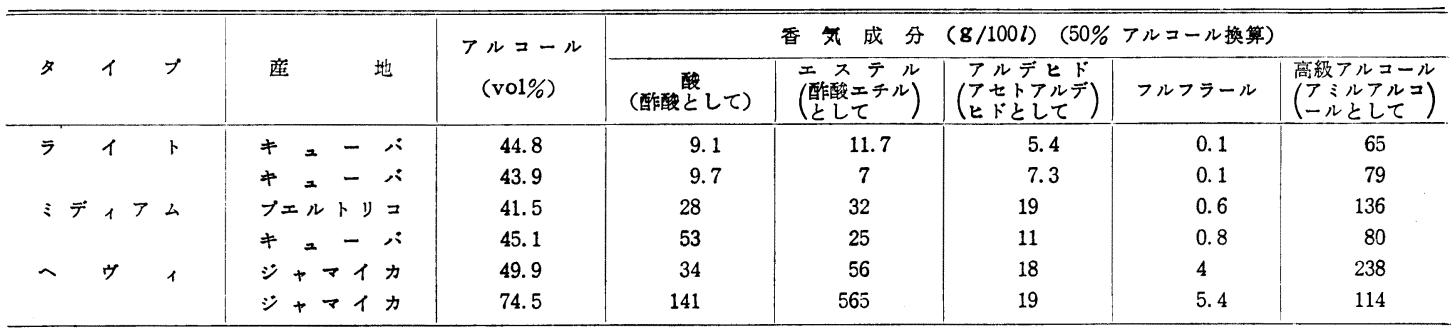


第 3 表 ジャマイカラムの醪組成

\begin{tabular}{|c|c|c|c|}
\hline 原 & 組 & 成 & 比 \\
\hline 蜜 & & $10 \%$ & \\
\hline 蒸留廃液 (ダンダー) & & $10 \sim 40$ & \\
\hline 浮迶（スキミング） & & 30 & \\
\hline 水 & & $50 \sim 20$ & \\
\hline
\end{tabular}

ヘヴィラムの場合は香気成分の生成のために醪にダン ダーを加えることが多い、1,4,5,6)。ダンダーは蒸留廃液を 放置してバクテリヤの自然発酵によって生酸させたもの で，3\%以上といら高濃度の酪酸や酢酸を含んでいる7。 このためへヴィラム工場の発酵室は Vinaigrerie（酢製 造所）と呼ばれたことがあっだ”。ダンダーを使用した ジャマイカラムの醪組成を第 3 表》゙に示す。

発酵は以前は自然発酵が多かったようであるが ${ }^{1,8)}$, 最 近では殆んどが純粋培養酵母を接種している。発酵温度 は香気成分の生成や散逸防止のためには $27^{\circ} \mathrm{C}$ を越えな いことが望ましいが，冷却コストや発酵時間などの点か ら通常は $31 \sim 32^{\circ} \mathrm{C}$ 以下で行なわれている。 $37 \sim 38^{\circ} \mathrm{C}$ に なると明らかに発酵阻害が認められる4)。

発酵の期間は36時間で完了することもあるが 3 週間続 く場合もある。平均的には $3 \sim 4$ 日である 後24４8時間放置してから蒸留する。

\section{2. 酵母について}

\section{2-1 ラム酵母の研究}

ラムの発酵は通常の糖蜜アルコールの発酵とは全く異 なったものであり，両者の違いを要約すると第 4 表”の ようである。酵母も当然区別して用いられており，アル コール発酵では発酵速度が速くアルコール収率の良い酵 母が望ましいが，ラム酵母はエステルや高級アルコール などの香気成分を多く生成することが必要である。

また前に述べたようにラムには種々のタイプがあるが 製造しようとするラムのタイプに最も適した酵母を選択 することが重要である。一般的に言ってへヴィラムには Schizosaccharomyces が適し，ライトラムには Saccharomyces が良いとされている年。

ラム酵母に関する報告は少ないので研究の経緯を知る

第 4 表 アルコール発酵とラムの発酵の比轒

\begin{tabular}{|c|c|c|}
\hline & アルコールの発酵 & ラムの 発 醉 \\
\hline 糖 分の資 化 & $\begin{array}{l}\text { 酰中の糖をすべて資化す } \\
\text { る }\end{array}$ & $\begin{array}{l}\text { 跴中の糖の大部分を資化 } \\
\text { する }\end{array}$ \\
\hline 発 酳 期 間 & できるだけ短期間 & 適当な期間 \\
\hline アルコールの生成 & 最大限に生成する & 比較的多く生成する \\
\hline 香気成分の生成 & 可及的少なくする & 充分量を生成する \\
\hline 発 醉 方 法 & 標準の発酻方法で可 & $\begin{array}{l}\text { 作ろらとするラムのタイ } \\
\text { プに応じ種々の方法で } \\
\text { 行なら }\end{array}$ \\
\hline
\end{tabular}

ことは出来ないが, 数十年間にはもっぱら発酵歩合が大 きな問題であったようで, 酵母の培湌方法や接種量, 菌 株によるアルコール生成量や糖消費率などの研究が散見 される $8,10,11$ 。

また当時はまだ自然発酵が多く行なわれていたが，ア ルコールの収率が理論値の 40 ～60\% しか出ない場合が あり，効率的，経済的なラム製造のために純粋培責酵母 の使用を奖めている報文も見られる ${ }^{1,8,11)} 。$

その後の研究は製造工程における各種酵母の分

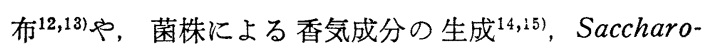
myces と Schizosaccharomyces の比較研究 ${ }^{14,15)}$ な゙が 若干行なわれている。これらについて次に概要を述べる。

\section{2-2 製造工程から分離された醳母}

糖蜜や甘蔗汁，発酵醪中の酵母の分布については SHEHATA, PARFAIT らの報告がある。SHEHATA ${ }^{12)}$ は ブラジルの 5 ヶ所のラム工場及びパイロットプラントに おいて各工程から酵母を分離した。それによれば第 5 表 に示したように，甘蔗汁にはSaccharomyces, Candida， Pichia が多く見られ，Torulopsis や Kloeckera なども 出現しているが, 自然発酵醪中では発酵性の弱いPich ia や Torulopsis は消隇し, Saccharomyces が優位を占 めていた。

PARFAIT ら ${ }^{13)}$ は西インド諸島のラム工場における酵 母の分布を調べた結果，第 6 表に示したように原料中に はSaccharomyces が主で，その他に Torulopsis, Candida などが分離されているが，発酵醪ではSaccharomyces が圧倒的に優勢であった。

これらの報告によれば発酵醪中ではSchizosaccharomyces の出現は極めて少なく Saccharomyces が主導的 となっている。最近のラムはライトタイプのものが多い ので，上記の調査もライトラムの醪であったと考えられ るが，そのような醪中ではSchizosaccharomyces より増 殖の速い Saccharomyces が優勢となるのは当然である う。一方, 以前のようなへヴィラムの醪ではダンダーの 添加によって酸度が高くなるので Saccharomyces は増 殖を阻害され，耐酸性の強いSchizosaccharomyces が 主体となって発酵が行なわれていたものと推論される。

\section{2-3 Saccharomyces と Schizosaccharomyces}

現在, ラム酵母として使用されているのは S. cerevisiae, S. carlsbergensis, Schizo. pombe などである が, Saccharomyces と Schizosaccharomyces は非常に 異なった特質を持っているのでその差異を良く知った上 で使い分ける必要がある。

まず発酵速度について見ると, 糖蜜培地に S. cerevisiae 或いは Schizo. pombe を $1 \times 10^{6} / \mathrm{ml}$ 接種して発酵 させた場合，第1 図 ${ }^{14)} に$ 示したように Schizo. pombe 
第5表製造工程から分離された酵母(I)

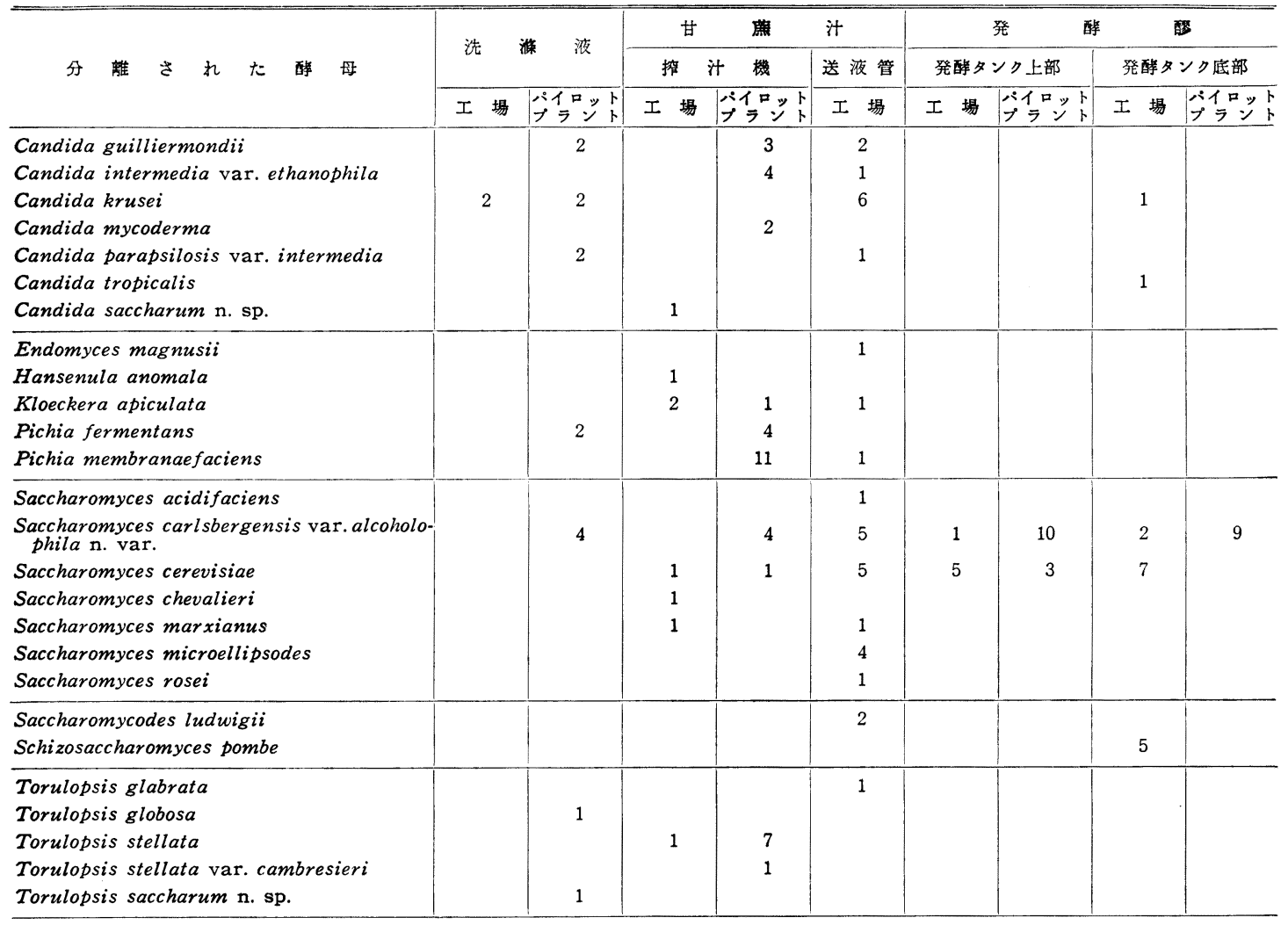

数字は出現頛度を示す。

第 6 表 製造工程から分離された酵母 (II)

\begin{tabular}{|c|c|c|c|}
\hline 分離された醉 & 糖 蜜 & 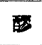 & 発酻終了配 \\
\hline Saccharomyces cerevisiae & 10 & 19 & 15 \\
\hline Saccharomyces chevalieri & 3 & 5 & 4 \\
\hline Saccharomyces rouxii & 1 & 1 & 1 \\
\hline Saccharomyces aceti & 1 & 5 & 3 \\
\hline Saccharomyces microellipsoides & - & 1 & - \\
\hline Saccharomyces delbrucki & - & 1 & - \\
\hline Saccharomyces carlbergensis & - & 2 & 1 \\
\hline Schizosaccharomyces pombe & - & 1 & 1 \\
\hline Pichia membranaefaciens & - & - & 1 \\
\hline Hansenula anomala & 2 & 2 & 2 \\
\hline Hansenula minuta & - & - & 1 \\
\hline Candida krusei & 1 & - & 2 \\
\hline Candida pseudotropicalis & 1 & - & - \\
\hline Candida tropicalis & 1 & - & - \\
\hline Torulopsis candida & 2 & - & - \\
\hline Torulopsis globosa & 3 & - & 1 \\
\hline Torulopsis glabatira & 4 & 2 & 3 \\
\hline Torulopsis stellata & 1 & 1 & - \\
\hline
\end{tabular}

数字は出現頻度を示す。

の方が 2 ～ 3 日発酔が達れた。Saccharomyces に比べて Schizosaccharomyces が発酵が遅いことは他にもいくつ

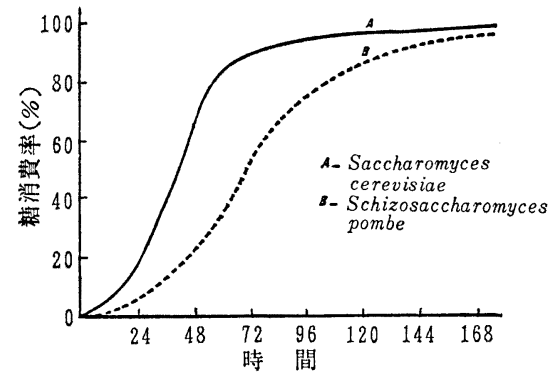

第1図 ラム酵母の糖消費率

かの報告がある通りである ${ }^{3,17) 。 ~}$

耐酸性は，0〜0.3\% の酪酸を添加した培地に夫々の 酵母を $1 \times 10^{8} / \mathrm{ml}$ 接種して培養した結果, 第 7 表 ${ }^{14)}$ に示 したようにS. cerevisiae は酸濃度が高くなると増殖が 阻害されたが, Schizo. pombe は阻害は認められず耐酸 性の強いことが確認された。

次に香気成分の生成について示す。まずエステルであ るがラムのエステムで最も多いものは酢酸エチルで, 全 体の $50 \%$ 以上を占める。実験例 ${ }^{14)}$ では酢酸エチルの生 
第 7 䒾 ラム酵母の耐酸性

\begin{tabular}{|c|c|c|c|}
\hline & \multirow{2}{*}{$\begin{array}{c}\text { 酸 濃 } \\
(\%)\end{array}$} & 醇 & 数 / $\mathrm{m} l$ \\
\hline & & S. cerevisiae & Schizo. pombe \\
\hline & 0 & $22 \times 10^{6}$ & $8 \times 10^{6}$ \\
\hline & 0.05 & $14 \times 10^{6}$ & $6 \times 10^{6}$ \\
\hline & 0.1 & $13 \times 10^{6}$ & $3 \times 10^{6}$ \\
\hline & 0.15 & $10 \times 10^{6}$ & $2 \times 10^{6}$ \\
\hline & 0.2 & $10 \times 10^{6}$ & $6 \times 10^{6}$ \\
\hline & 0.25 & $1 \times 10^{6}$ & $3 \times 10^{6}$ \\
\hline & 0.3 & $1 \times 10^{6}$ 以下 & $7 \times 10^{6}$ \\
\hline
\end{tabular}

成量は S. cerevisiae が $500 \mathrm{mg} /$ 純アルコール $1 l$ であっ たのに対して, Schizo. pombe は1,000 mg/純アルコー ル $1 l$ と 2 倍量の生成がみられた。高級脂肪酸のエチル エステルについては第8 表 ${ }^{15}$ に示したように Saccharomyces, Schizosaccharomyces 及び Pichia, Candida, Hansenula などの中で Schizo. pombe の生成量が著し く多かった。またエステムの組成も酵母によって差異が 認められたが醅母細胞脂質の脂肪酸組成との相関は得ら れなかった ${ }^{15)}$

高級アルニールについてはSaccharomycesの方が生成 量が多い、14,17)。Schizosaccharomyces を用いて製造した ヘヴィラムの高級アルコール含有量が多いのは, 共存す るバクテリヤの作用によるところが大きいと考えられる。

また Schizosaccharomyces は著量のグリセロールを 生成する (第 9 表) ${ }^{18)}$ 。グリセロールは留液には移行し ないのでラムの香味に対して直接の影響はないが，乳酸 菌などのバクテリヤがグリセロールを資化してアクロレ インやその誘導体を生成するためにラムの風味を損うこ とがある。

以上述べたように Schizosaccharomyces は発醅は晕 いが耐酸性があるのでダンダーを加えた酸の高い醪でも よく発酵し，またエステル生成能が強いことなどから， ヘヴィラムの製造に適している。一方， Saccharomyces は発醅が速く副成分の生成が少ないのでライトラム に用いられる。

\section{3. バクテリヤについて}

\section{3-1ラム製造に関与するバクテリヤ}

PARFAIT ら ${ }^{18)}$ はラムの製造工程において出現するバ
第 9 表 酵母によるグリセロールの生成

\begin{tabular}{|c|c|c|c|}
\hline \multirow{2}{*}{ 登 } & \multirow{2}{*}{ 醉 時 昆 } & \multicolumn{2}{|c|}{ クリ七ロ一ル生成量 $(\mathrm{g} / \mathrm{l})$} \\
\hline & & S. cerevisiae & Schizo. pombe \\
\hline & 0 & 0 & 0 \\
\hline & 6 & 0.8 & 0.1 \\
\hline & 12 & 1.1 & 0.4 \\
\hline & 24 & 1.5 & 9.3 \\
\hline & 36 & 1.6 & 9.3 \\
\hline & 48 & 1.8 & 9.3 \\
\hline & 72 & 2.8 & 9.6 \\
\hline
\end{tabular}

クテリヤを分離した（第 10 表）。これらの中で䤃酸菌は

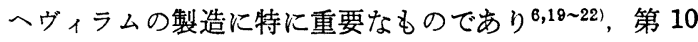
表でRhum grand aróme(芳香の強いーヴィタイプのラ ム）の醪にClostridium が多く存在していることもそれ を裏付けている。へヴィラムの製造において純粋培養し た酪酸菌を接種することがよく行なわれ，Clostridiumsaccharobutyricum が特に良い結果が得られている ${ }^{6,21)}$ 。 生成酸の $90 \%$ が $\mathrm{n}$-酪酸で, 他に酢酸, プロピオン酸, カ プロン酸などが含まれておりこれらの酸は最終的には エステルを生成しへヴィラムの主要な香気成分となる。

前に述べたようにへヴィラムの醪はダンダーを混合す ることがよくある ${ }^{1,4 \sim 8)}$ 。ダンダーは蒸留廃液を貯蔵熟成 させたもので，酪酸菌や䣫酸菌が增殖して多量の酸が生 成されているのでこれを醪に添加することによって揮発 酸やエステルの多いへヴィラムを製造することが出来 る。これらのバクテリヤは糖やアルコールに対する耐性 が弱いので醪中で增殖し生酸することは難しいが，ダン ダーは既に充分に酸を生成蓄積しているので醪中ではそ れ以上の生酸を期待しないで良いわけである。

また乳酸菌はグリセロールを資化してアクロレインな ぞを生成しラムの香味を低下させると言われている。,10)。

\section{3-2 酪酸菌の応用}

酪酸菌がへヴィラムの製造に拈いて重要な役割を果し ていることは前述の通りである。酪酸菌の応用について ARROYO ${ }^{21)}$ は発酵型糖度が $6 \%$ 以下，フルコール分 が 3.5〜4.5\% になった時点で酪酸菌の培養液を加える のが良いと述べている。接種量は酵母の $1 / 5$ 程度が良 く，接種後は $\mathrm{pH}$ が 5.0 以下にならないよらに調整す る。

第 8 表 各種酵母による高級脂肪酸エステル生成量 ( $\mathrm{mg} /$ 純フルコール $1 \mathrm{l}$ )

\begin{tabular}{c|c|c|c|c|c}
\hline \hline & $\begin{array}{l}\text { Pichia } \\
\text { membranaefaciens }\end{array}$ & $\begin{array}{l}\text { Hansenula } \\
\text { anomala }\end{array}$ & $\begin{array}{c}\text { Schizosaccharomyces } \\
\text { pombe }\end{array}$ & Candida krusei & $\begin{array}{c}\text { Saccharomyces } \\
\text { cerevisiae S. 132 }\end{array}$ \\
\hline ethyl caprylate & 20 & 1 & 28 & 4 & 19 \\
ethyl caprate & 72 & 12 & 108 & 9 & 70 \\
ethyl laurate & 39 & 7 & 47 & 6 & 18 \\
ethyl myristate & 6 & 2 & 7 & 1 & 3 \\
ethyl palmitate & 3 & 7 & 6 & 3 & 4 \\
\hline (合 & (1) & $(28)$ & $(196)$ & $(22)$ & $(114)$ \\
\hline
\end{tabular}


第 10 衰 製造工程から分離されたバクテリヤ

\begin{tabular}{|c|c|c|c|c|c|c|c|c|c|}
\hline \multirow{2}{*}{ 分離されたバクテリヤ } & \multicolumn{2}{|c|}{ 原 } & 料 & \multicolumn{3}{|c|}{ 配 } & 発 & 醇 & 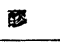 \\
\hline & A & B & $\mathrm{C}$ & A & B & C & A & B & C \\
\hline Enterobacteriaceæ & H & - & - & + & - & - & - & - & - \\
\hline $\begin{array}{l}\text {-Escherichia } \\
\text {-Eruvinia }\end{array}$ & H & - & - & - & - & - & - & - & - \\
\hline $\begin{array}{l}\text { Acetobacter } \\
\text { Streptococcaceæ }\end{array}$ & - & - & - & + & - & - & + & + & - \\
\hline -Leuconostoc & + & - & - & + & - & - & - & - & - \\
\hline $\begin{array}{l}\text {-Pediococcus } \\
\text { Micrococcaceæ }\end{array}$ & + & - & - & + & - & - & + (発醉初期) & - & - \\
\hline $\begin{array}{l}\text {-Micrococcus } \\
\text { Peptococcaceæ }\end{array}$ & + & - & - & + & - & - & + (発酻初期) & - & - \\
\hline $\begin{array}{l}\text {-Sarcina } \\
\text { Bacillaceæ }\end{array}$ & - & + & + & + & + & + & $H$ & H & + \\
\hline -Bacillus & + & + & + & H & H & \# & + & + & + \\
\hline -Sporosarcina & + & - & - & + & + & + & - & - & - \\
\hline $\begin{array}{c}\text {-Clostridium } \\
\text { Lactobaciliaceæ }\end{array}$ & + & + & + & + & + & H & + & H & m \\
\hline -Lactobacillus & + & - & - & \# & 世 & + & + & + & + \\
\hline
\end{tabular}

H, H, +は出現㖽度の大小を示す。

A, B, Cはラムのタイプの遇いで, Aは Rhum agricole (甘蔗汁から作ったラム), Bは Rhum mélasse (結蜜から作ったラム), Cは Rhum grand aróme (芳香の强いヘウィタイブラム) である。

著者らはラムの酸に酪酸菌を接種し生酸させることを 試みたが，酪酸菌の糖耐性，アルコール耐性が弱いため に発酵醪中で酸を生成させることは非常に困難であっ た ${ }^{23)}$ 。そこで低濃度の糖蜜培地に酪酸菌を接種して充分 に生酸させ、これを裂に加えることによって風味の強い ラムを得た ${ }^{24)}$ 。既ち糖度 $3 \%$ の糖蜜培地にClostridium butyricum ATCC-6015 を接種し酪酸発酵させたものを 醪に 5 30\% 添加し，同時にラム酵母を接種して発酵さ せた。これらの蒸留液の酸とェステルの含有量は第 11 表年) に示したようにいずれも高くなって损り，特に酸の 增加が著しかった。官能的には $15 \%$ 以上の添加で風味 増強の効果が認められた。

また苲留廃液と精製残液の混合液を放置して自然発酵 によって酸を生成させたものを通常のラム醪に加えて発 酵させた結果, 酸, エステル及び高級アルコールが顕著 に増加し，非常に風味の強いラムが得られた25)。

以上ラムの製造に 関する 微生物について 概要を述べ た。ラムはドリンク用としての用途が增えてライト化の 傾向にあり，発醅が速く香味成分の生成の少ない製造法 が主流になってきている。しかしラムは元来, 高温の西 インド諸島において糖蜜の自然発酵によって作られたも のであり，そこには各種の酵母と酪酸菌、酢酸菌など種 タのバクテリヤが巧みに関わり合っていたと思われる。 その詳細については充分に明らかにされていないが, この自然発酵の中にこそラムの本質が隠されているわけ であり，今後の研究が期待されるところである。

おわりに文献調查に協力戴いた当社中央研究所の中野
第 11 表 酪酸発酛裂の添加による酸, エステルの 增加

\begin{tabular}{|c|c|c|c|}
\hline \multirow{2}{*}{$\begin{array}{l}\text { 酪酸発醉酸の } \\
\text { 添加量 }(\%)\end{array}$} & \multirow{2}{*}{$\begin{array}{l}\text { 酗のアルュール } \\
\text { 濃度 }(\%)\end{array}$} & \multicolumn{2}{|c|}{ 留液の成 分 $(\mathrm{mg} / 100 \mathrm{ml})$} \\
\hline & & 酸（酢酸として） & $\begin{array}{l}\text { エステル(酢酸 } \\
\text { エチルとして) }\end{array}$ \\
\hline 0 & 8.6 & 20.2 & 39.4 \\
\hline 5 & 8.7 & 25.5 & 39.4 \\
\hline 10 & 8.4 & 32.6 & 39.4 \\
\hline 15 & 7.6 & 41.4 & 40.6 \\
\hline 30 & 6.6 & 101.2 & 45.6 \\
\hline
\end{tabular}

山路氏並びに東京工場技術課の中野敏夫氏，松田孝之氏 に謝意を表する。

（合同酒精株式会社）

\section{文献}

1) PRESCOTT : Industrial Microbiology p. 198(1959)

2) R. ARROYO: Sugar 36, DEC. 26 (1941)

3) J. N. PATURAU : By-products of the Cane Sugar Industry 204 Elsevier Publishing Co., (1982)

4) J. A. P. I'ANSON : Process Biochemistry 6, JULY 35 (1971)

5）浜口栄次郎，河本正彦：糖蜜ヘンドブック，240, 精糖工業会 (1967)

6) W. H. KAMPEN : Sugar y Azucar JULY 36 (1975)

7) H. WÜstenfeld, G. HAEsLeR : Trinkbranntweine und Liköre 73 75 Paul Parey, Berlin und Hamburg (1964)

8) R. ARROYO: The International Sugar Journal, Nov. 292 (1947)

9) R. ARROYo: Sugar 37, Jan. 29 (1942)

10) R. ARROYO: The International Sugar Journal Feb. 42 (1950) 
11) R. ARROYO: The International Sugar Journal June 163 (1949)

12) A. M. El-Tabey Shehata : Appl. Microbiol. 8 73 (1960)

13) A. PARfait, G. SABIN : Ind. Aliment. Agric. 9227 (1975)

14) B. G. PARFAIT, A. PARFAIT : Ind. Aliment. Agric. 97575 (1980)

15) A. PARFAit, M. NAMORY, P. DUbOIS : Ann. Technol. Agric. 21 (2) 199 (1972)

16) E. AqUARONE, M. L. BRAZZACH, E. ANGELINO : Rev. Fac. Farm. Bioquim. Univ. Sao Paulo 1, (2) 141 (1963)

17) A. Parfait, C. Jouret : Ann. Technol. Agric. $24,(3 \sim 4) 421$ (1975)
18) A. Parfait, C. Jouret : Ind. Aliment. Agric. 97721 (1980)

19) L. FAHRASmane, A. PARfait, C. Jouret, P. GALZY : Ind. Aliment. Agric. 100, 297 (1983)

20）朝井勇宣 : 酵素化学工業全集, No. 8, 254, 厚生 閣 (1939)

21）友田宣孝: 微生物工学講座, No. 4, 259, 共立出 版 (1958)

22) R. ARROYO: The International Sugar Journal, Apr. 101 (1946)

23）根元 茂, 杉本仁太郎, 薄井 隆 : 䤑協 70, (3) 197 (1975)

24）根元 茂, 杉本仁太郎, 薄井 隆 : 醸協 70, (3) 201 (1975)

25）未発表 